応立にち教 1りやな問移くし

おのあで充、扱過移題動異、社

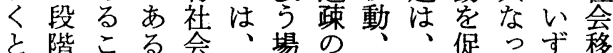

と階こる会そ等の閏と教進てれ動

てあのと二れで題く䏍守くをと社

る宿は般自あをにをるる従教

と証命、に体る生地独少。属育

も左で教兄。域立、教変の

かとも䏍何し考し間変あ育数問

くも社々 $九$ め の数るとと題

、いり会と極てる移といくしに

本え、学教めみと動考はにてつ

稍そさ分充てるい方え移々取い

でうら、し幅とう、る動のりて

はでにもと広、の地方手水扱

あいといいっは域向様準

社るえもう内社、ので態のかそ

会。ばとテ容会教教あを上にの

社

会

移

動

移方方、を移育充り変昇よい

動の法 1 マふ動を問、容やっず

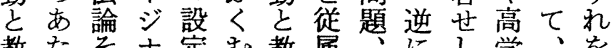

教たそナ定む教属这にし学、を

青りのルのの青変ためめ歴意独

とのもな仕でし数と人る化味立

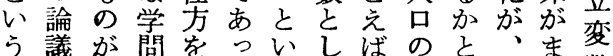

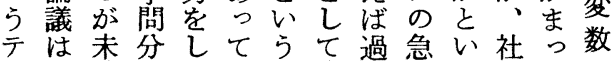

1 一確野が、テ取密激う会たと

と

教

育

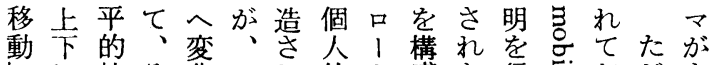

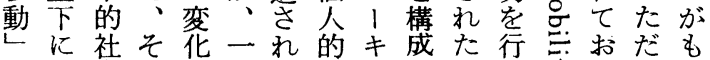

配会れ寸つ变もンす内な过く本つ

列移がるの容しにる容っに必論内

きさ動同こ社さくあ社をてに要要容

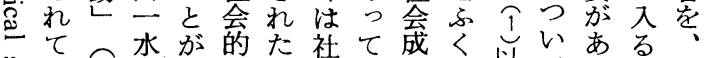

吃準社位も会は員え以て来て前甚

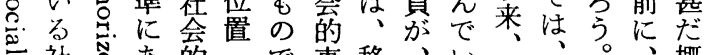

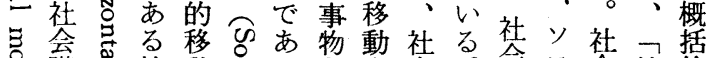

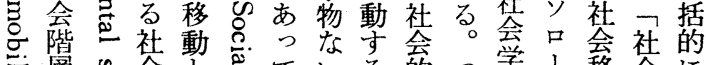

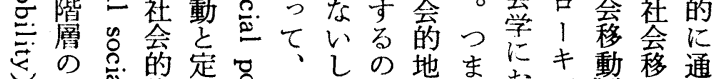

松

間总位義导々価は位りおお憅移通

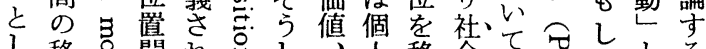

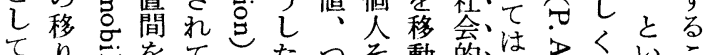

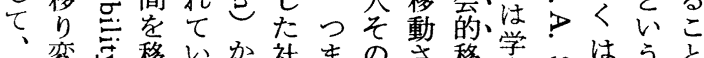

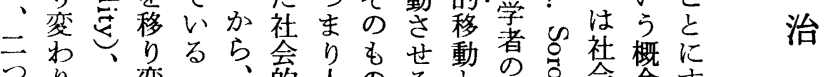

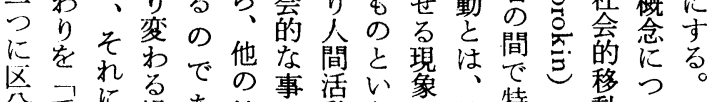

分重対昜あ社物動うを社特が動い

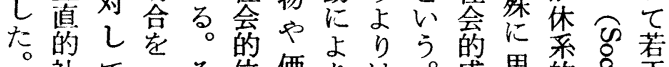

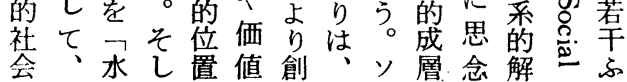




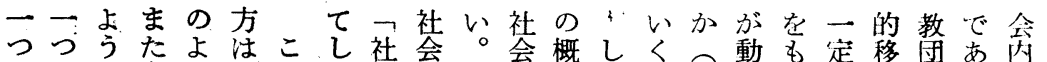

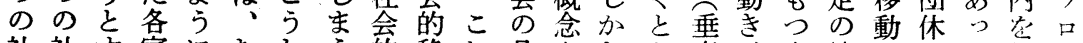
社社す家にむしう的移れ具としか值人人精でにて価 会会る族社した。移動に休ほなな的拿の神あ動、䛧手 層層方成会ろ社動でよ的と孞ど移芝間的るくたやン

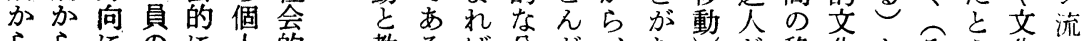

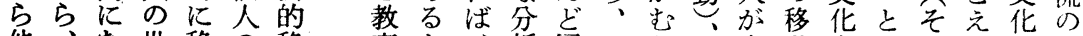

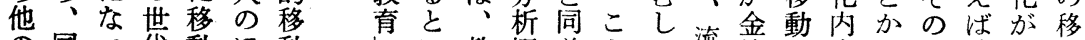

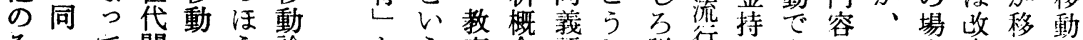

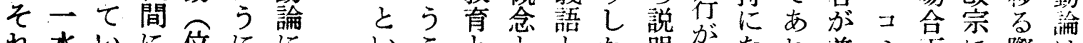

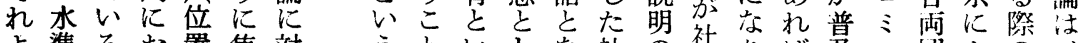

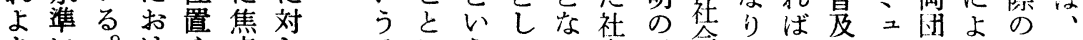
りに。けや点し テにうてっ会材会: 水し二休っ法社 もあっる地をて、な社はて的料位資平てヶなて則会

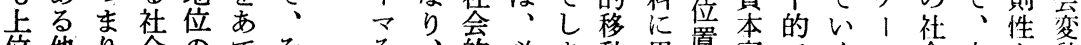

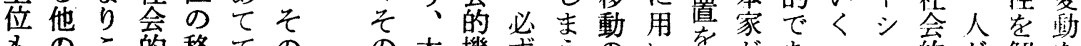

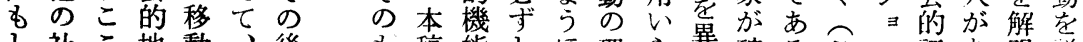

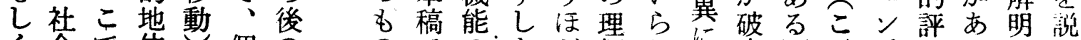

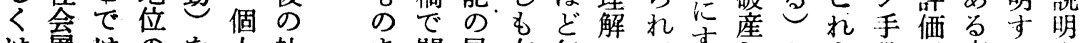

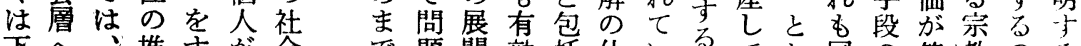

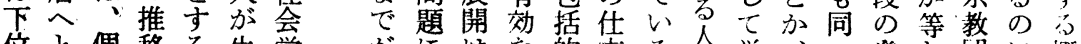
位と個移る生学㤎注的方る人学、発し団に概 の移人なか涯で無する゙道で注。令働階の達け休用念

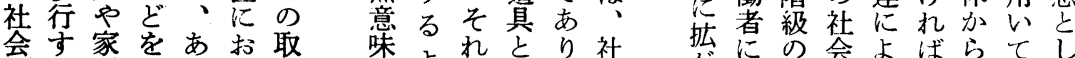
会す家を族るい取味よれとり社势に势会よばらてし

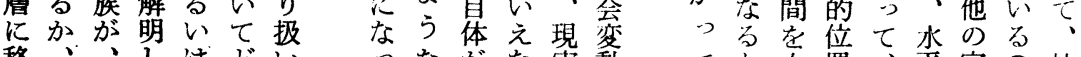
移、、しはどいっなが策動てと置、平宗の社

違

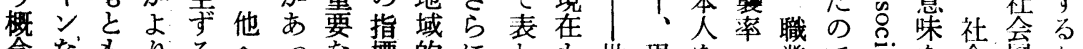

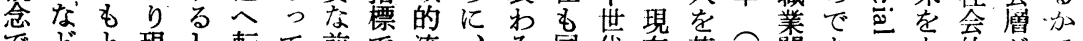
でどと現し転て前で流々同代在基父間あ心的台で あの寒、入、提あ動昭う一内の準親移る表分成、移

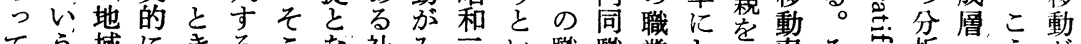

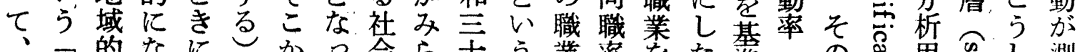

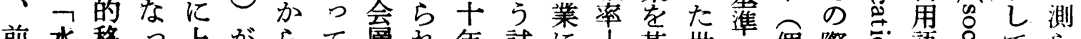

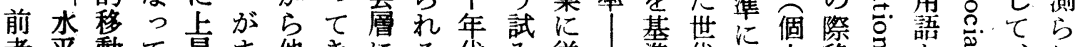

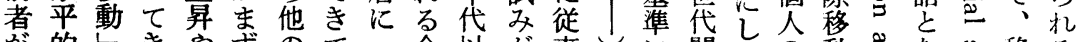
が的しきやずのて二今以が事、に閳たの動艺な气移え

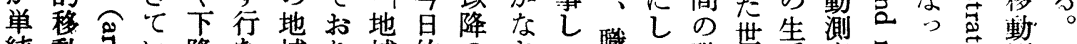
純動怘い降な域り域的のさて職て職代活定志て芯測

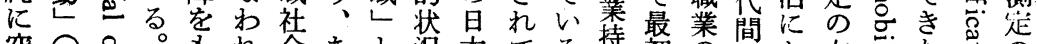

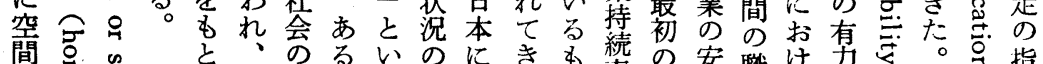

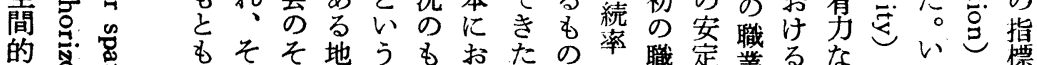

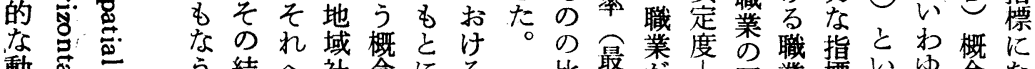

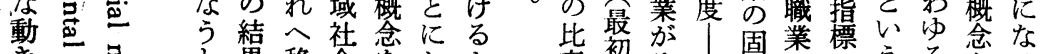

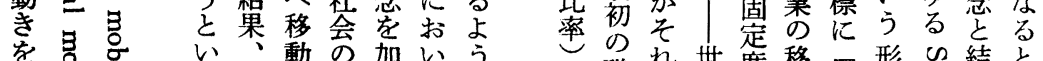

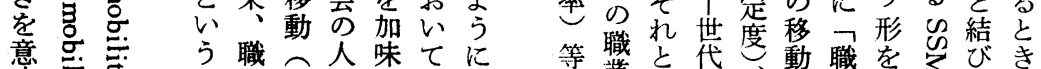

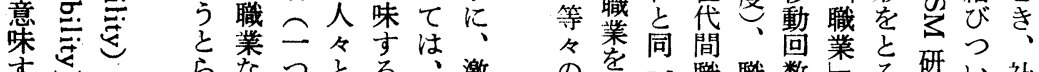

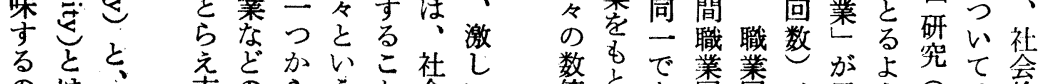

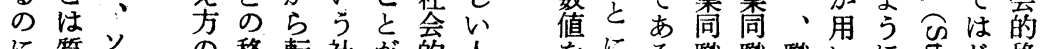

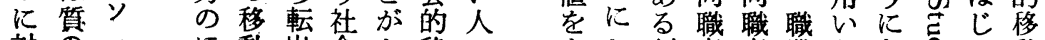
対の口重出会よ移口割率率業らな参め動 
差流ゆしま動

をれえたで社ま

作えに人以会ず

り。的上に教

上そと資にある党

る結ぜ・々て独

こ果え熊の泣亲

に地こは域教 数

な域衣、的充、

る閪之そ移の社 にしれ動普会

学、七を学䇟

歴静、需激、動

別態人要し教を

人面を守く充従

口つ地るさ水属

構ま域産せ準変

成り間業て 数

の人に社 い学と

地吕移会る歴考

域構動の。の え

差成 せ地教上る

がのし域充莽な

生上め的が

ずでる偏生、ば

万の 形在 みこ

の格での出れ変
の研活い介、る動以るる社日し も究動はにるい进以なのれ会のて とをの諸しこはい上くにて的よ

二です展個なと垂うのな、い位う後 辿方開人がが直とよっ地る置な者 ろめののら妥的きうて域のの変 引る上地、当なににい的で移動社 ととに域そで社々るる・動期会 いい諸的のあ会個ての空り定の的 うう々移個ろ的人くで間、目社位 の方の動人う位吕るあ的ま的会置 で向問をの。置地なる移たににの あを題と社つの域ら。動いしお移 る、学会ま移的ば学いたい動 ᄀ投な的り動移、前かりてを 社げっ位教整こ動こ提えあはい 会かた置育いをことれる、っ

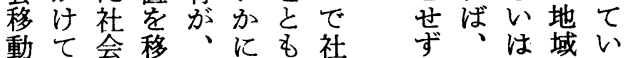
とい的行個展な会社々的る。 教る移せ人開い的記会れ。 育、動しのさな移述的に空し ᄂとのめ地せが動守位結間か とい激て域てらなる る置び的し いっしい的い、いわのつなな うたさく移る水しけ移い移が テ観が、動か平社に動て動ら、

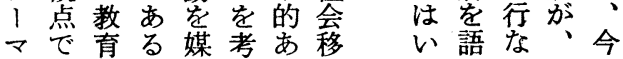

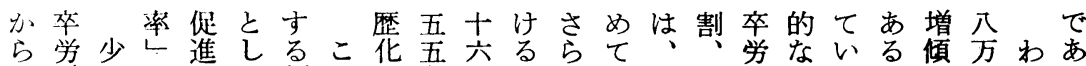
過働なを年て側うを\% 年高にき中高働こる。向三がる 度力く停る。のし示に等昭た学等力と若に手国。 にはと滞が第産た卞大注和中卒学のはは年あ人に

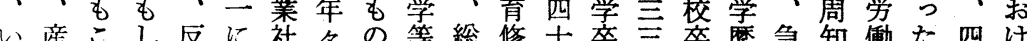

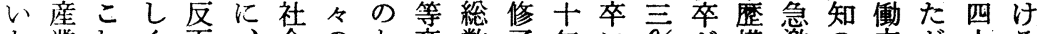
わ業れく面、会のと卒数了年に $\%$ が構激の妿が十る ゆのまはでその新さ三一者代か約成にとの、一新 る地で低第れ態規れ三六の前わ高四は進こ供そ年規 先域にめ云ら勢労て\% 公割半っ校割、行ろ給れに労 進的おてに新が働いこ万合期て卒と昭すで減には働 地分いし、規、可るほ二をの、五い和るあは反三可

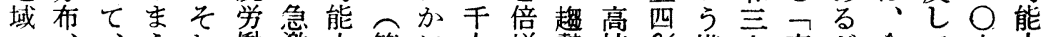
へ、，れ働激人第に人増勢校\%構市高が今て六人 と労高こら力に口 1 中のせ注卒成五学、後四万口 流働学とのの休の表退うし、が逆で年歴だの十至の 動条歴に人可質高荐号め新大転あで化が日年手数 し件化な人地変学 2 四、、規宗しつはとそ本代人沙

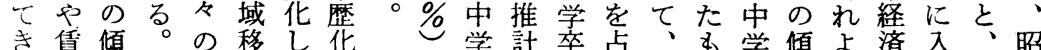

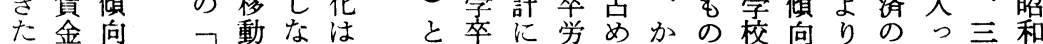
格を率い: 一文働るつが卒でも重て产 た差示昇范労 となし的をぎ働 えどた 社いり力 ばの・新 昭 諸 規 和点学

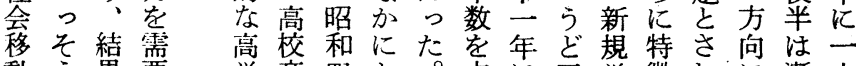
飛九机妿にて、があ、垂減年干 躍\%ばのい過四ちるさ問少代五 的、なた半十よ。ら題の後年 動 引果要学卒四打。占に五学徵れに漸六 
あ就規て先るち四 る職学み進が、十 い者卒る杢|県三 は堂と業|年 岩占動第県い会 手め力 2 とい就 ならの表後か職高 ぞ机集の進えし校 でて中ご農れた卒 はい率と業ばも業 るるはく県県のの 高こ三でと外は就 校亡○あいか三職 卒に○るわら无者 のな\%令れの。

半るを过る就五全 数。こと五職\% 国 な之え之都率つで い九府三元 乙に半に県九着 そ対分東等公三 れし以京つ吾二

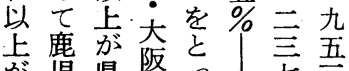

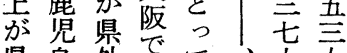
県島外湓比こ人人 外宮ら紫こでの 流崎の新しをあう
第 1 表 新規労働可能人口の推移とその学歴構成 (単位 :\%)

\begin{tabular}{l|c|ccc|cr}
\hline & (千計 & \multicolumn{2}{|c|}{ 新規 学卒労働力 } & \multicolumn{2}{c}{ 中途退 学者 } \\
\cline { 3 - 6 } & 中学校 & 高等学校 & 大学等 & $\begin{array}{l}\text { 高等学 } \\
\text { 校段階 }\end{array}$ & $\begin{array}{c}\text { 大学等 } \\
\text { 段階 }\end{array}$ \\
\hline 35年 & 1,682 & 50 & 39 & 8 & 2 & 1 \\
41年 & 2,063 & 33 & 54 & 10 & 3 & 0 \\
46年 & 1,681 & 19 & 55 & 22 & 3 & 1 \\
\hline
\end{tabular}

（注）1.「学校基本調查」ベースによる。

2. 新規学卒の推計は下記による。

i ）中 学 校.......中学校卒業者見込数から当該年 4 月 の全日制高等学校 (本科) および高 等専門学校入学者見込数を引いたも の

ii）高等学校......全日制高等学校 (本科) 卒業者見込 数から当該年 4 月の昼間部大学・短 期大学入学者見込数を引いたもの

iii) 大 学 等......昼間部大学・短期大学、高等専門学 校卒業者見込数
四立立立立向た述た立地そ方出 九・・五る。なの結な県 - 七一年の地方後果い外 四\%\%\%域な,進はっか $\%$ 之 ら

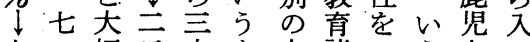
七。幅三干ま人諸いう島 - 五に・五で条っまでて 五\%伸七年もの件そ无は

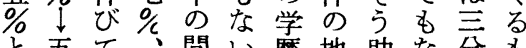
と五て、間い歴地助な分も と五る䯩にが男别域長々ののの く\% の教子た成差る的し勘 に、に䏍のと比にこ能 短九対修後え注沙方 大州し了期ば、称にと ・で、者中関全かない

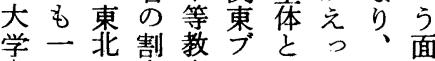
卒五で合育口してさに の芒はが修ッて、らお 占 $\overline{0}$ 二三了ク高覀にい め\%三三者で度循そて る上・・のは化環れ、 割市三三割、のをが遅 合 $\overline{\%} \%$ 合昭傾到後机
第 2 表 高校卒業就職者の県内外移動 状況

（昭和 43 年 3 月）

\begin{tabular}{|c|c|c|c|}
\hline & $\begin{array}{l}\text { 県外への } \\
\text { 就 職率 }\end{array}$ & $\begin{array}{l}\text { 県外から } \\
\text { の } \\
\text { 就 職 率 }\end{array}$ & $\begin{array}{l}\text { 新賛学卒 } \\
\text { 篗力率 } \\
\text { 集 }\end{array}$ \\
\hline
\end{tabular}

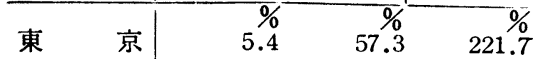

$\begin{array}{llll}\text { 大 阪 } & 4.0 & 54.1 & 209.3\end{array}$

神 奈 川

受 知

$18.1 \quad 51.1 \quad 167.2$

$\begin{array}{lll}5.4 & 37.1 & 150.3\end{array}$

$24.9 \quad 31.4 \quad 109.5$

$\begin{array}{lll}44.9 & 4.9 & 57.9\end{array}$

$52.7 \quad 5.6 \quad 50.1$

$68.8 \quad 3.0 \quad 32.2$

$\begin{array}{lll}39.3 & 2.6 & 62.3\end{array}$

$\begin{array}{lll}49.0 & 3.3 & 52.7\end{array}$

\begin{tabular}{llllr} 
全 & 国 & 29.5 & 29.5 & 100.0 \\
\hline 就職者_県外への_県外からの
\end{tabular}

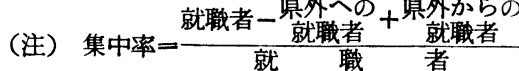


第 3 表 学 歴 別 構 成 比

(単位 : \%)

\begin{tabular}{|c|c|c|c|c|c|c|c|c|c|c|c|c|}
\hline & & & 男 & & & 子 & & 女 & & & 子 & \\
\hline 地 & & 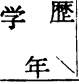 & 就学 & 竖中 & 高專 & 大学 & 計 & 未就学 & 䖯 & 但高専 & 大学 & 計 \\
\hline & & 昭25 & 75.3 & 14.7 & 7.3 & 2.7 & 100 & 81.7 & 16.6 & 1.6 & 0.1 & 100 \\
\hline 全 & 国 & 35 & 68.8 & 20.8 & 4.7 & 5.7 & 100 & 74.2 & 23.5 & 1.9 & 0.4 & 100 \\
\hline & & 昭25 & 80.8 & 12.1 & 5.5 & 1.6 & 100 & 87.2 & 11.8 & 0.9 & 0.1 & 100 \\
\hline 北海 & & 35 & 74.0 & 18.9 & 3.5 & 3.6 & 100 & 79.9 & 18.7 & 1.2 & 0.2 & 100 \\
\hline & & 昭25 & 80.2 & 12.3 & 6.1 & 1.4 & 100 & 87.2 & 11.5 & 1.2 & 0.1 & 100 \\
\hline 東 & 北 & 35 & 78.8 & 15.7 & 3.0 & 2.5 & 100 & 83.4 & 15.1 & 1.3 & 0.2 & 100 \\
\hline & & 昭25 & 70.6 & 16.1 & 8.6 & 4.7 & 100 & 79.8 & 17.7 & 2.3 & 0.2 & 100 \\
\hline 関 & 東 & 35 & 61.2 & 22.7 & 6.0 & 10.1 & 100 & 68.8 & 27.5 & 2.9 & 0.8 & 100 \\
\hline & & 昭 25 & 79.1 & 13.0 & 6.1 & 1.8 & 100 & 85.3 & 13.5 & 1.1 & 0.1 & 100 \\
\hline 東 & 海 & 35 & 72.9 & 19.3 & 4.0 & 3.8 & 100 & 78.3 & 20.0 & 1.5 & 0.2 & 100 \\
\hline & & 昭25 & 80.5 & 11.8 & 5.9 & 1.8 & 100 & 87.1 & 11.8 & 1.1 & 0.0 & 100 \\
\hline 北 & 訟 & 35 & 75.1 & 18.1 & 3.8 & 3.0 & 100 & 81.8 & 16.8 & 1.2 & 0.2 & 100 \\
\hline & & 昭 25 & 73.0 & 16.0 & 7.7 & 3.3 & 100 & 78.1 & 19.7 & 2.1 & 0.1 & 100 \\
\hline 近 & 鿨 & 35 & 62.9 & 24.9 & 5.4 & 6.8 & 100 & 69.1 & 28.1 & 2.3 & 0.5 & 100 \\
\hline & & 昭 25 & 72.8 & 17.6 & 7.6 & 2.0 & 100 & 74.9 & 23.3 & 1.7 & 0.1 & 100 \\
\hline 中 & 国 & 35 & 70.9 & 21.8 & 4.2 & 3.1 & $100^{\prime \prime}$ & 71.1 & 27.0 & 1.7 & 0.2 & 100 \\
\hline & & 昭 25 & 79.9 & 12.3 & 6.3 & 1.5 & 100 & 83.9 & 14.8 & 1.2 & 0.1 & 100 \\
\hline 四 & 国 & 35 & 77.0 & 16.7 & 3.5 & 2.8 & $100^{\prime}$ & 78.9 & 19.9 & 1.1 & 0.2 & 100 \\
\hline & & 昭25 & 75.3 & 15.3 & 7.4 & 2.0 & 100 & 81.5 & 17.3 & 1.1 & 0.1 & 100 \\
\hline 九 & & 35 & 72.1 & 20.4 & 4.3 & 3.2 & 100 & 75.3 & 23.2 & 1.3 & 0.2 & 100 \\
\hline
\end{tabular}

注「国勢調査」による（35年は1\%抽出結果）。

力二通な散ま弱た先たひる数に始純形三て的動準心が

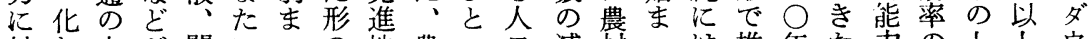
対な大唯開いっの地農つ口減楖っは推年た力の上 すど量、発まて学域符に再退地てい移にがの高真のン

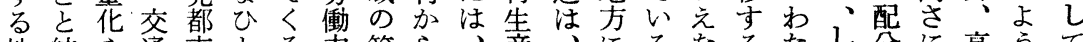
地結や通市とる力第ら、産、にるなるたし分に高うて 方び広穴のつと供至のこ等相お若いかっか上つ学にい のつ域、展にみ給次都れの対け年。ぼてしにな歴しる

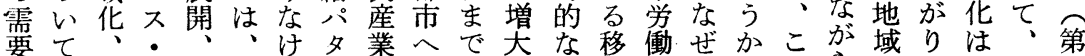
の、文二観工れ、学のの、先動力なにれら、格、、こ 伸高花ミ光業ばン支流特あ進哥のらつ恕今差結それ表

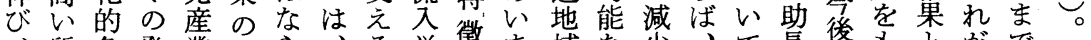
、質条発業地ら、る学徵ま域な少、て長後すとがで 地の件達の地な次と動でっに労、すはさ辰たし地教 方労の発方い第い力あてお働さで、れ的域育 生働画流澾分。にっがっ、け力らに単る年し人移水 
にかとのさのと

対ら、なれ低関次 し.いさかて下連に てっらでいに遇 産大学よいも規 側務・ににふら働 加系短か、れ市可

ら労大わ急て第能

の働卒つ激打至人

労力のてに<

働の割高生こ問の

力供合校じ 亡 題高

需給の卒てに学

要を急がきしす歴

の相上大たよな化

中対昇宗こうわが

心的は艺の。ち、

はに、占傾こ雄

、増労め向れ上存

こ加働る、も犁の

れさ力新方的産

ませ供に嫢で社業

でる給い学に会社

にが側た卒多移会

引、のっ労く動 の

きこ要た働指率体 業事学卒うてた労

続れ請。こ少摘七筫

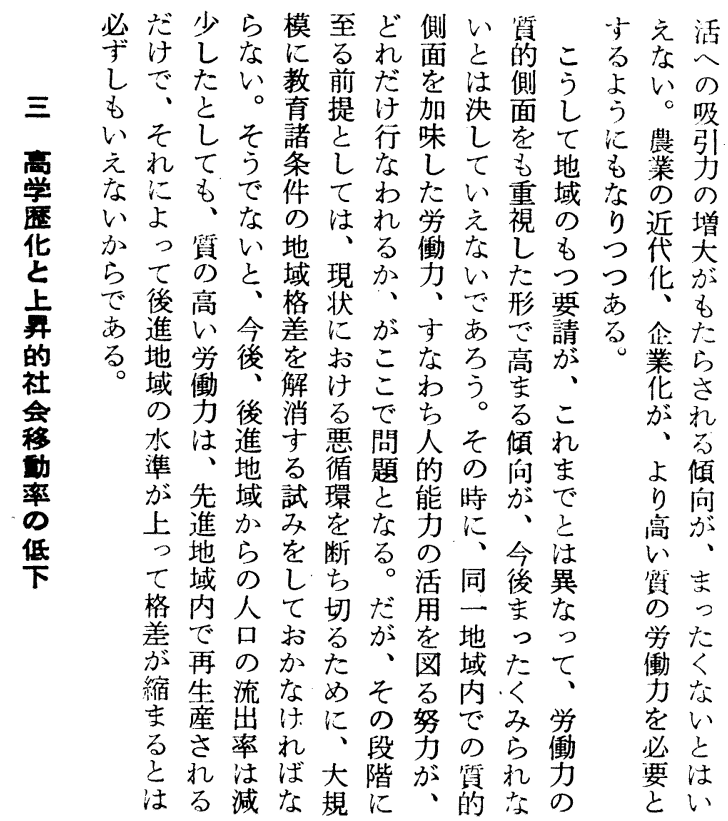

必な゙少ら模至ど側い算こ蓑省活 しだたい教前だをは側うよいの 当。”育提け加決面しう。吸 いそしそ諸と行味しをてに㻃引 なにもで件ておたい重域な香の いよ、なのはれ労え視のり近堌 かっ貿い地、る働なしもつ代大 らてのと域現か力いたつつ化が だ後高、格状、、だ形要市、も あ進い今差にがすあだ請る企た 域働、解けこおう学訛さ の力後消るでち。るこ茫

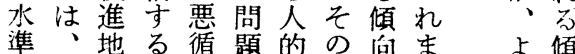
が先域試環と能時がでり向

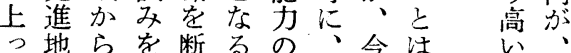
て域のし号。活同後異路ま 格内人て切だ用一交なのう 差で口お方がを地っっ学た

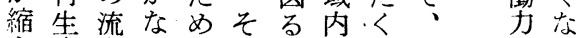
ま産出けにの努でみ労をい

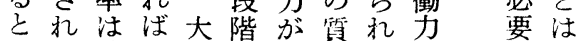
はる減な規に、的なのとい

四一へ業能ををがでの

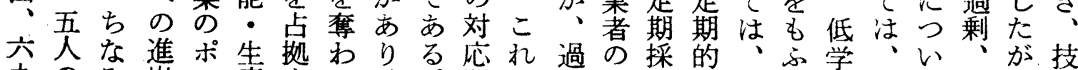
が業定定てをてに過しき 九のみ出不産玄れ、。関ら去供用にそく磨現て従っ能 人うにを言るた二ま係のの給制、のめ層状注来て労 でち和ぎ鹪程々高方ずの結も增度均生てので絶は、㗢

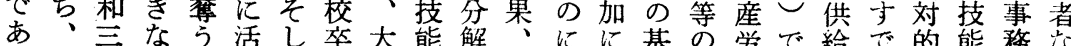
口専十くく基の学で給で的能務な

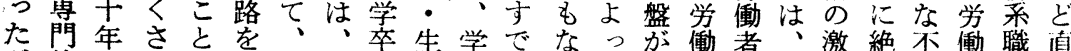
が的にれの求そ服卒磨な゙なっが働者、激絶不働職值 技足力種接 一術け。る ○的る る。部加程職じ 年的蔀門にや業つ 後業学つ㔔進っ壳ダあ のに卒た中出てに、る 照入两大高学し専占下現 和 力四学校卒、門め降象 四た年卒卒の中的る現は 十子制 のか主学技中象衣 年的占要卒術学徒 にの就半専なに的卒来 はは職壮門職か職の清の 約者的場わ業比水職 就半七販技でっの率義業 職数 $\bigcirc$ 売術あてポの弘॥ 者恶部的るこ不減饾学 つ学れ大要のとな問給の廒 あ歴は量を中多不題源志に る偏じに充学な足との向従 重め採足校っのな中性事 のて用でてて状っ心がす 賃いすき高、態てと強る 金るるな等ほにいない労 雇さいく学とさる。っ高㗢 用らっっ卒どなとき歴に 制にたて業のっくたに傾 度ま、お者企てに中打斜 そた従り、の業い後学いし の、来、みてる者卒てて の大ま計に大。学浽い も学で面よ企つ動供る。 の卒の的っ業以力給。 
第 4 表 大学卒の職業別就職者数の推移

\begin{tabular}{|c|c|c|c|}
\hline & 昭和30年 & 35年 & 40年 \\
\hline 専門技術的職業 & 34,692 & 42,603 & 59,071 \\
\hline 技 術 者 & 8,951 & 19,239 & 30,888 \\
\hline 内 教 員 & 23,360 & 17,963 & 21,722 \\
\hline 医療保健 & - & 1,967 & 2,023 \\
\hline そ他 & 2,381 & 3,434 & 4,438 \\
\hline 管理的職 業 & 788 & 1,400 & 2,459 \\
\hline 事梨哥 & 25,505 & 39,822 & 45,859 \\
\hline 売 & 2,924 & 9,518 & 20,170 \\
\hline 農 林 漁 業 & 403 & 461 & 212 \\
\hline 運 輸 通 信 & 220 & 329 & 899 \\
\hline 保 安 職 業 & 582 & 544 & 492 \\
\hline サービス職業 & 871 & 1,624 & 2,616 \\
\hline そ の 他 & 4,030 & 3,405 & 3,641 \\
\hline 計 & 70,015 & 99,706 & 135,419 \\
\hline
\end{tabular}

（注）文部省「日本の教育統計』
出増四べがてとた人数

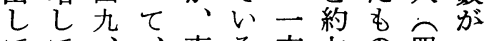
てて、事る方七の四一 い、三技務への倍は三三 るか○能照高に: ・五 つ ○工販和校ふ三六 第七人売至卒市\%四 5 中か生に干のて年立 表学ら産つ年就いのに九 。卒四工い三職る三と人 が十程て西者第九充立 压年作は○第九倍 倒に業ほ:つ4 4 三り増 的注者五心表四、兄 に一主云て造人たた 占六ブ倍九梳れに

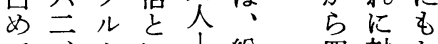
て、1い!総四対少 い八.5四数十七か た七力ふ十に年てわ こ四亏之年しに、ら の人、方七て泪撯 職としで ○े 壳 業至があり や○従五 に倍三る三注一事九 大以幅上文に四倍 七者

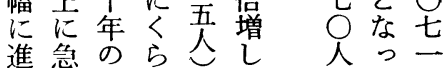

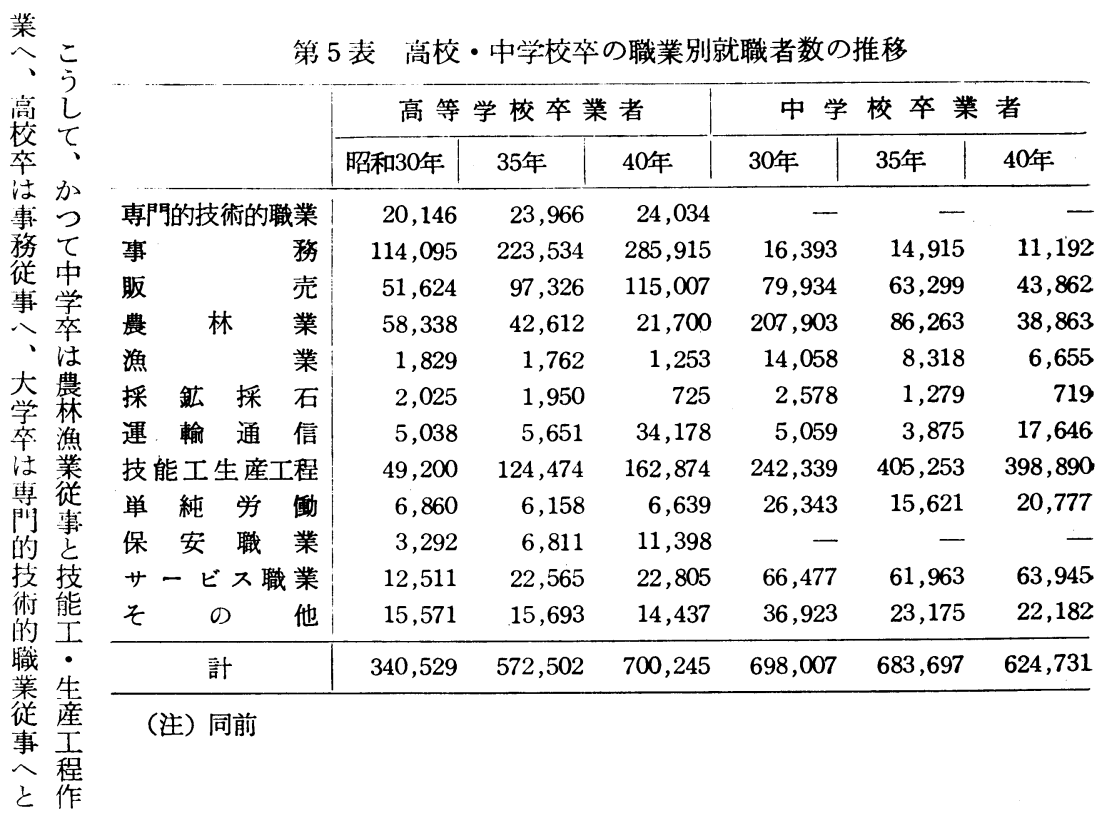




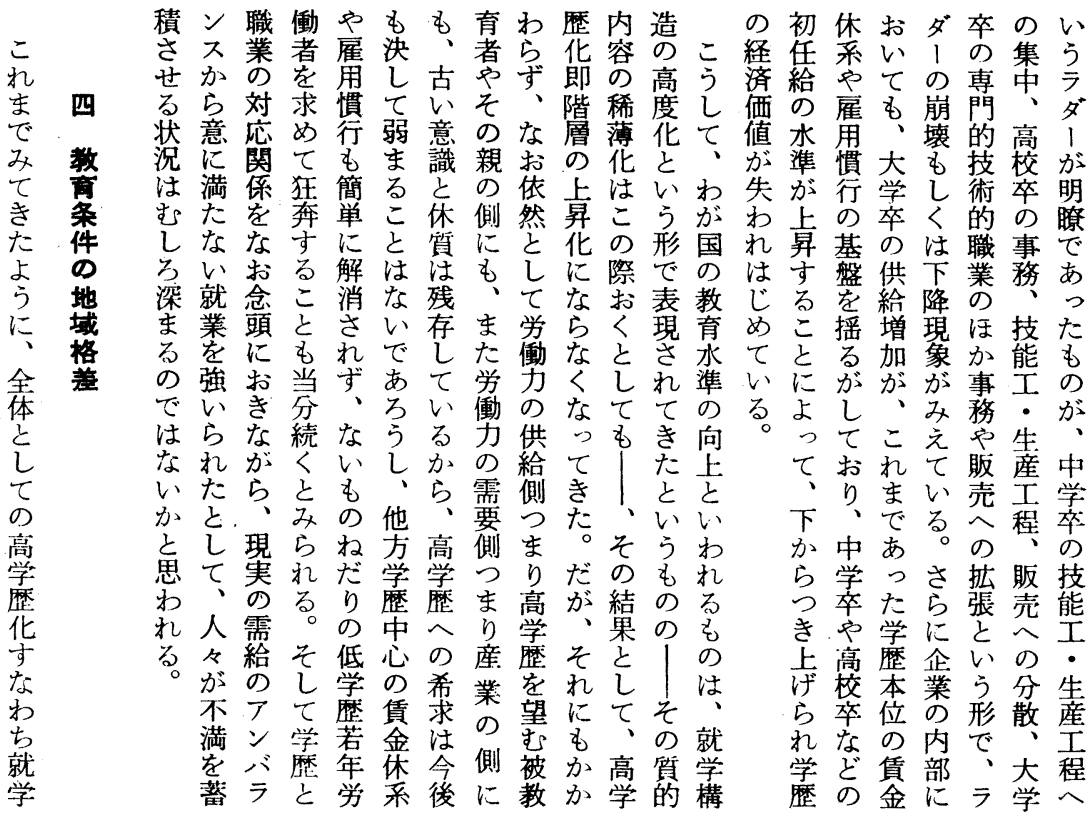

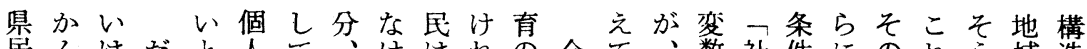
民んはだと人て、けはれの今て、数社件にのれら域造 所ずそがさのい経れ、ば目さみそと会の後もら助移の 得くの理れ属る済ばひな的らるれし移上進の産長動高 の地比念て性。的なとら沭こに動で地に業寺を度 高域率はいや前地らしな、゙と移教との域格のると化 い格にとる社者位なくいあるにる充教格の差先役すは

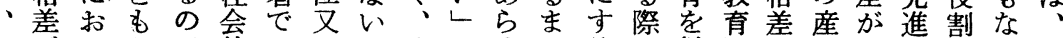
いがいかで的ははもそとゆでるの従市業存地さい産 わ存てくあ地、門のの定るむ。橋属を增の在域えな業

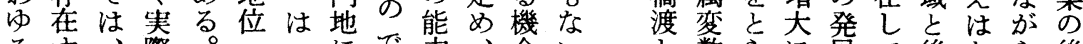
るす、際。・つにで力、会い

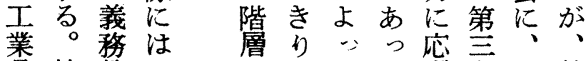
県第教、 と 6 㕕教扡、、る第ら姢 表学充域教人教市基 所に除を它格充種育項る本

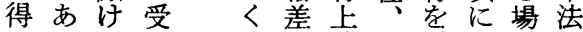
のるばけ格㤎差信受お所治 低よ、㕻否別条けいに いう明い方定さ歪たそ 農にらる あされ性機もいの

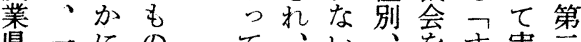

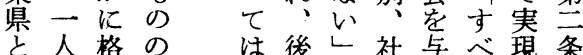
ら全格数 は後し社与べ現条 間た宁棉明的らのれ にりなる な注記れ国な教

し数らに展て後たら後 ととえはをい進し、進 し学习停る地てか地 て第称滞域いえ域 教りのえしこの。 育扱視つめの間々遅先 にう点てる地にれれ進 お方つくこ域はでた地 け向まると移、な地域 るにり。に動教く域へ 格つ社そよの㕕てのと 差な会こっ激をも後い のが移でてし与、進う 問っ動問、さえも性労 題てを題教はるとを働 起く独注青、条む心方 考る立、諸さ件とっの 
赔

奻

の

占

に率県とうてい子域にえにと育か前業促もし欲高こ

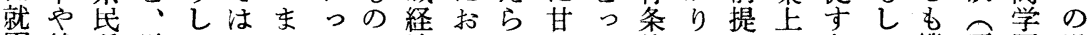
園就所単た、にその済いれえた件でにの条れ機要歴場 率学得純教地てう発発ててじ地になお後件な会求者合 が率やに䏍域幼助展展もいな域まくい進とい均しを、 工に産きへに稚長をへ、るけかで、て性しけ等の需義 業お業めの現園しおの質これら、内不がてれの上要務 県い構て意在就てく刺のとばのも容利、のど理で妾教 にて成か欲高園しら激高にな流しとををす高も念の竞 匹、のか、い率ませ汃いもら出格し強な学、が差上範 敵大上る要教やう、失労なな労差ていわ歴与を古で囲 寸きでわ求㕕上こてわ働るい動がのて方のでこあの外 るなちけがを級とい机力と力あ学い教意になる差で

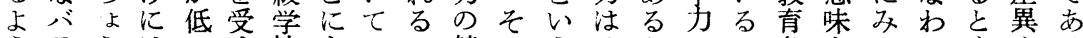
うラうはいは校も汇こ競れう泩とのこ条をてれすや なツどいかた進な全と争ば就じす水之件考きてれ、か 高キ中から労学る体にをか業めれ準にのえたいば本ら さが間なそ働率のとな通り機かばをな格るよるる をあのいう力のでしるじで会ら、左る差なうとそおこ 示り県。な低あてかてはの不そ右。注らにはれよれ す、のなっのいるのら期な制利うす単、将、いをびら 県岡場せて需地。地、待い約なしるなえ、地えも親地 山合ない要域域地さ。条就たよるの地域なっの域 岡・らるやに格域れ地件業点う学移域移いて教社 山山就ばの、お差そる域を条でな歴動の動の必充会 ・㘹、たそいをの地内与件打教ばの産をかず意の 


\section{社会移動と教育}

と低関い響っ中こ練は中大をきをいのにてなる奈 の:東っをそしれ所、し学注わ人。大設あ格うくか良 相で・て受してもで一てにっめ都置ら差のてか・ 関て近、悟てい全は県いいきてあと市主たがはもる山

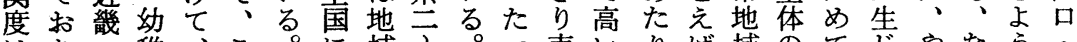

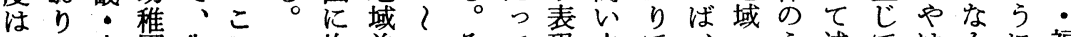
加、中園先れ均差一そて琴水で、へう述てはえに福 な所国・にら等は○のはし準比大の芯くくりら井 り得地高みににき力ほ四てを較学集私るる教か必苾 高水方等た対配わ所か○い示す、中的まこ育のずよ 以準に学よ応 。やお校うし

と教い:にて く育て大地

に施高学域進 学設々我差学 - 準 北大示 短の海へすこ 大地道のこの に域・就と施 差東園に設 いと北率なの て進・・る存 は学杂焦。在 率州学一哭 その地率 般況 れそ方は的の 莯れで、に影 置めで職\%るしる短傾なでとのきしう さて比業以。、大向ももの機っもに れ大較訓上大東、なやのなあ会か地進 てき的練学京関ど、のくるにけ元学 いい均機学の心東の機占、のめでに率 るし等関生三大臨教関め幼をぐ高その が、にに数 $\overline{0}$ 阪海育数る稚予まいれか ま分つか％・ブ社の比園想れ准ほな 各た布いら前京口会地率やさて学ぞり 種工しては後都ッ資域の高せい率高高 学業ては半吕なク本差高等るるをいい 校高い分東どやのはい教のか示労県 は等る公近京へ近量き場育でいす働が 都専が立くにの畿へわ合機あなよ力あ 市閚:職があ大ブスめに関るいうへる 地学事業東り学口トてはな。かにのこ 域校業訓系、のッッて、ど にな需々

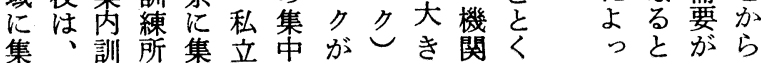

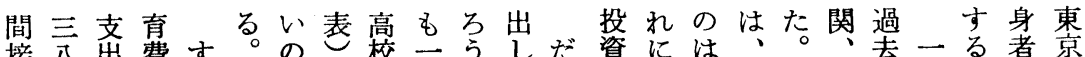

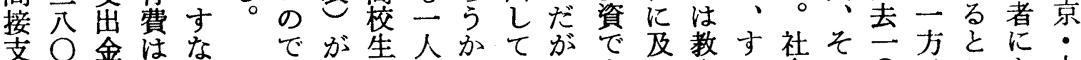

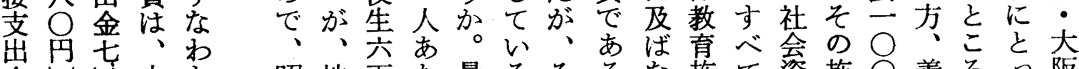

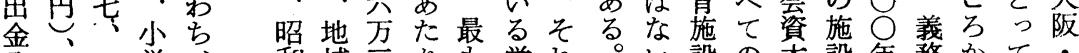
八中二学、和域兰り学れ 、虫校こ四差孚の新校に

八学亲校の

○校等五年

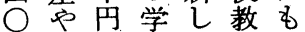
年階で校い充か 度層あ教学費か 两、学五児 分差る龍校にわ で○納交童 あ云付円生 る吕金教徒 、直科人 ににる費教おら つ関々㤝いず い亭いう小費でそ こ詳学推机 れ細照生計大ぞ 大直附学あ竞な和三艺きれ 阪接金習た み内四万はいの 支な費り る容四円、差地 は出ど・の と年中父が域 小金の通父沉四学兄あで 学二間学先次れ月学唯る実 校、接費支 ので五生支の際

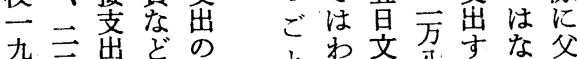
九三出ど の 九吾金直校 とか文分すな父 く省手究架 い設の本設年務かて こで辺のを間教らは京 とあ地地地の充、、都 がっを域域伝に著生な わてふ分的統おし活ど か、く析にをけく費に る他めで均もる進を集 。のてケ等つ教学ふ中 最い、1に日充機くし むか全不配本条会めて 地な国・置の件がてい 域るくス专学にせ相る 的種ま夕る校つば対の 片類なデに制いめ的で 寄のくィあ度てらに り社施をずははれ高こ の会設や少、どるいれ 少資艺っったらす教ら な本設たてしで㕕地 いの䈯か力市費域 社配しぎにろ定以 会㯰てぎが教う必外 資晋いりあ充か要の 本こるでっ機。と出 
上備教の育な差とテ受で権円にるこ支五七る中九 のな員格以こっはしスけあ利、高学と出分宁学出 問どの差外のて、てトるるの鹿い校のの円二に校へ 題、質がのほいさ表な児。あ児の教よ少し三対一直 点今の、教かるら現ど童しる島で紊うなと吾し八接 も後向地育、とにさに里たこ崖あ経にいい円て、支 こ注上域的教い同れよ生がぞ五る費考こう六出 こたと的環員うしてっ徒っも元ををえを鹿金

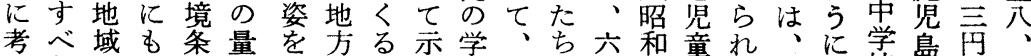

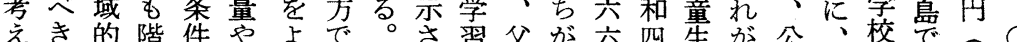
らこ均層の質くも第机条兄、四十徒ち共後二 れと衡的差示、7 る件支処円三元的者五小一五 るか化にな家し市表よの出遇地年人がに注、学、两 べら、もど庭て街のう差の上っ度あ、そ前○校八、 きは地こ、教い地よなと差こつのた実れ者吾二三間

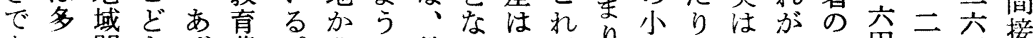
あい間むげ費。農に教っ、だ等学でそ力六円冎接 ろしのたれ出、育てそけ等校みうバ割へ三、出 う、調ち ば親村地のあののしでてだ!

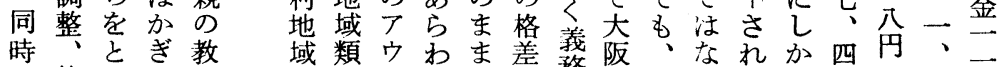

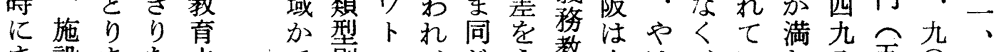

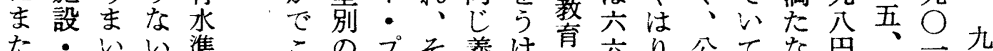

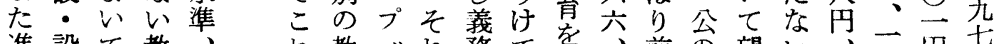

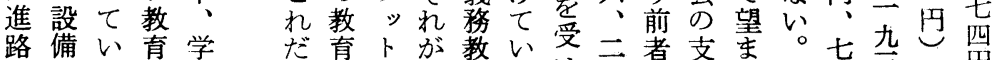

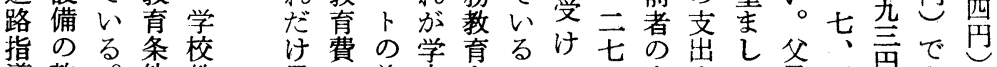

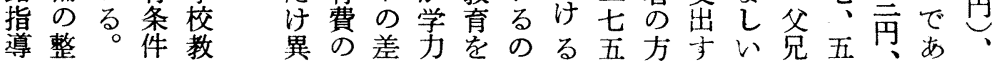

第 7 表 地域類型別にみた父兄支出の学校教育費（昭和40年度）

\begin{tabular}{|c|c|c|c|c|c|c|}
\hline \multirow{2}{*}{ 地 域 類 型 } & \multicolumn{3}{|r|}{ 校 } & 中 & \multicolumn{2}{|r|}{ 校 } \\
\hline & 学校教育費 & 直接支出費 & 間接支出費 & 学校教育費 & 直接支出費 & 間接支出費 \\
\hline 均 & $\begin{array}{r}\text { P } \\
15,536 \\
(100)\end{array}$ & $\begin{array}{r}\text { P } \\
7,156 \\
\text { (100) }\end{array}$ & $\begin{array}{r}\text { 円 } \\
8,380 \\
(100)\end{array}$ & $\begin{array}{r}\text { 円 } \\
20,027 \\
(100)\end{array}$ & $\begin{array}{r}\mathrm{P} \\
11,225 \\
(100)\end{array}$ & $\begin{array}{l}8,802 \\
(100)\end{array}$ \\
\hline A 市 街 地 域 & $\begin{array}{r}18,067 \\
(116)\end{array}$ & $\begin{array}{l}8,147 \\
(114)\end{array}$ & $\begin{array}{l}9,920 \\
(118)\end{array}$ & $\begin{array}{r}20,686 \\
(103)\end{array}$ & $\begin{array}{r}11,865 \\
(106)\end{array}$ & $\begin{array}{l}8,821 \\
(100)\end{array}$ \\
\hline $\begin{array}{l}\text { B 小都市 } \\
\text { 郊都市近 }\end{array}$ & $\begin{array}{r}15,920 \\
(102)\end{array}$ & $\begin{array}{l}7,397 \\
(103)\end{array}$ & $\begin{array}{l}8,523 \\
(102)\end{array}$ & $\begin{array}{r}20,953 \\
(105)\end{array}$ & $\begin{array}{r}11,938 \\
(106)\end{array}$ & $\begin{array}{l}9,015 \\
(102)\end{array}$ \\
\hline C 農山村地域 & $\begin{array}{r}13,644 \\
(88)\end{array}$ & $\begin{array}{r}6,309 \\
(88)\end{array}$ & $\begin{array}{l}7,335 \\
(88)\end{array}$ & $\begin{array}{r}19,445 \\
(97)\end{array}$ & $\begin{array}{r}10,817 \\
(96)\end{array}$ & $\begin{array}{r}8,628 \\
(98)\end{array}$ \\
\hline D その他の地域 & $\begin{array}{r}14,997 \\
(97)\end{array}$ & $\begin{array}{l}7,299 \\
(102)\end{array}$ & $\begin{array}{l}7,698 \\
(92)\end{array}$ & $\begin{array}{r}19,699 \\
(98)\end{array}$ & $\begin{array}{r}10,420 \\
(93)\end{array}$ & $\begin{array}{l}9,279 \\
(105)\end{array}$ \\
\hline
\end{tabular}

（）内は平均を 100 とする指数 


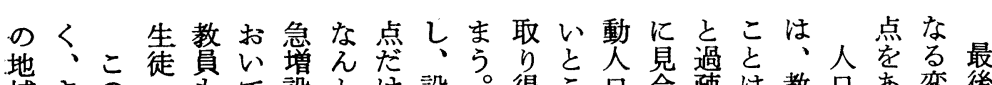
域さの文て設とけ設。得こ合䠅は教品変後

にら”人寄稀さ加な備最なろのうの、充移て花に五

もに恵市せ薄れ力ら拡もいか多教問す条動てが、

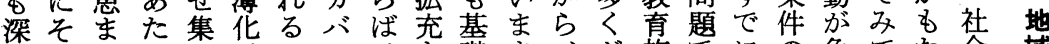

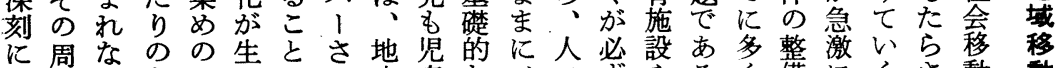

生边W条よしにれ方童な、吕ずやるく備にくさ動動

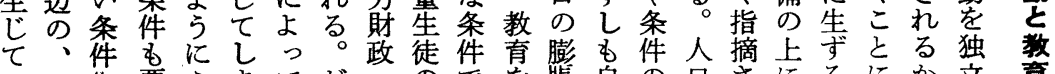

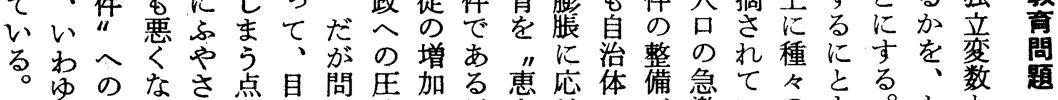

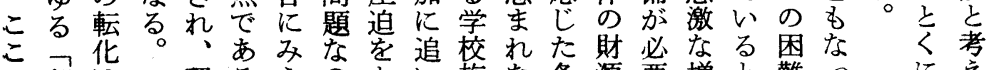

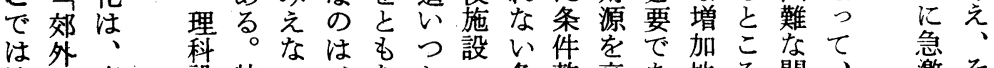

地化值設特い、なかっ条整高あ地ろ問、 激そ

方逃墇別形水いな校件備める域で題流なれ

かた的や教で增ない舎“にるにであがれ们に

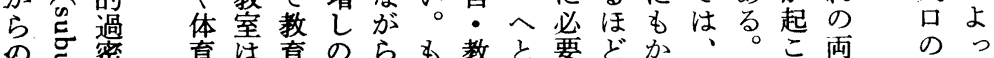

の密育看のらも教と要どか、。こ両のっ

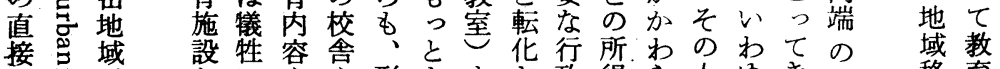

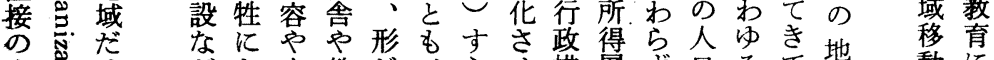

人音婂さ水教だ、らせ措層ず吕るて地動に

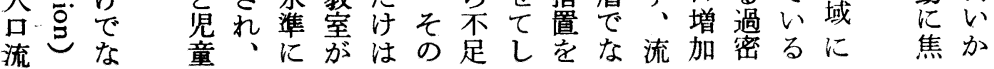

のにで点い育しは造す旦開条”地ま面力的なた速

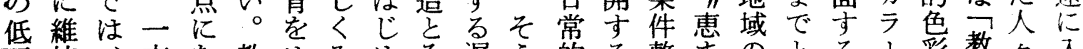

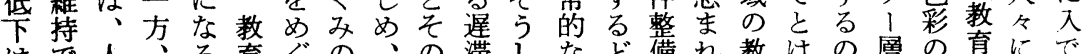
はで人、る育ぐの、の滞しなど備れ教はの層の育にで

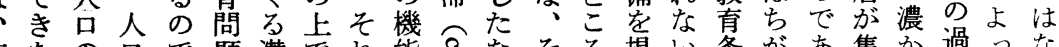
直なの品で題潜でれ能豆なそろ提い条があ集か過っな

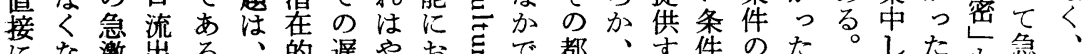

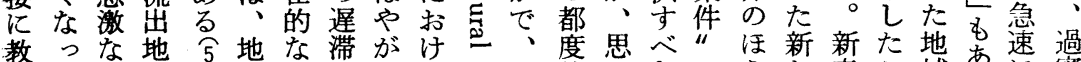

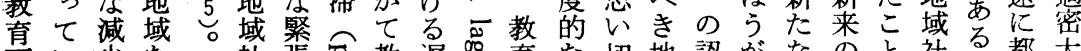
面い少な社張る教礠畜な切地認がなのと社る都大 にるのか会か育滞やを対っ域識々教層に会れ市都

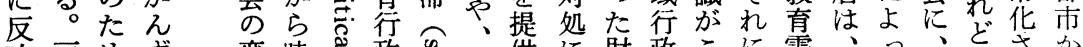

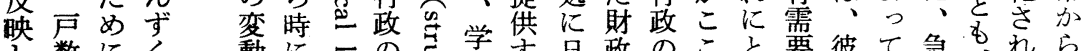

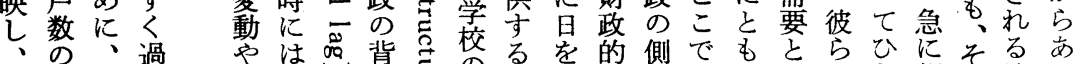
児減こ速新顕の後志制側過支に的でると測な要のき都そるあ 童少れ地し在のに製のご持は問わ求社お市む域れ

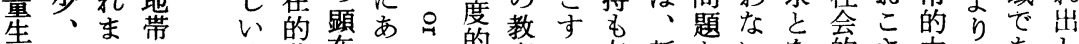

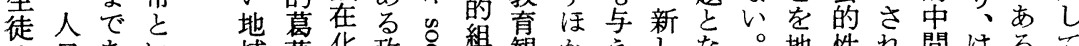

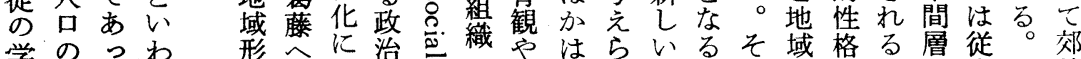

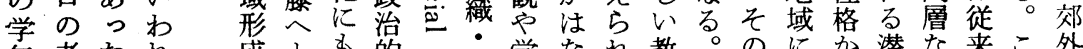

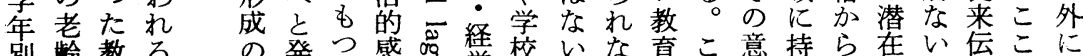

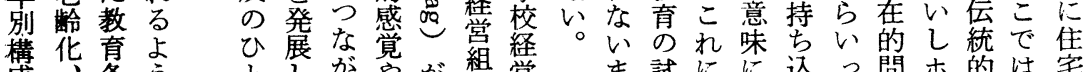

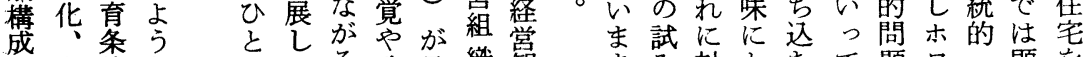

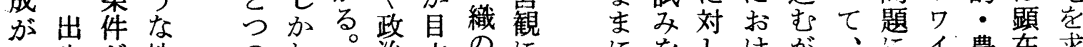

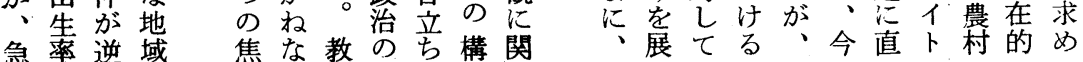




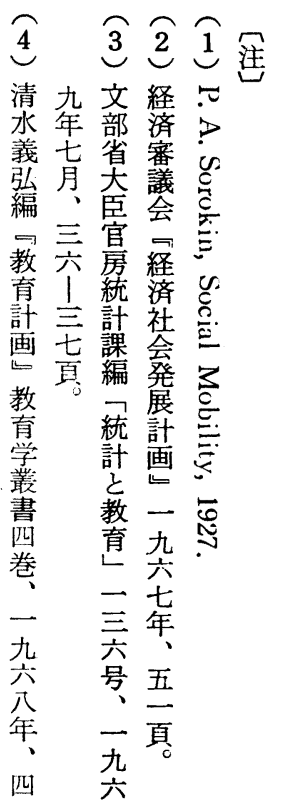

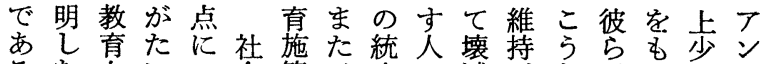

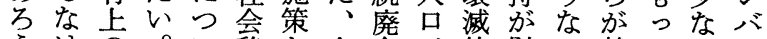
らけの。い移な全合が的財っ就てくラ れ問まて動ぞ体、減な政て学いなン ば題しのと盛と分少状的くするっ なをて解く可校守況にるる町てに ら生階明に込てのるがもとこでいな なず層は人社廃と作困教乃、るっ

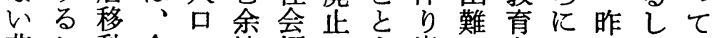
非こ動今の地福の娄出学海、 常とて旦地が祉方にさな展一のた一 に㠿域西的向机り開名出々年 多考乒ず移女姿を行る、さし生光生 くえやし動り勢辿政。父世か児ばの のあ下むがながろの過克る入数こほ もわ降充教い強う側蹯の条学务れう のせし分育のくをも方生件し三まが をるがににが、守自過活とな干で六 残なこ行何現そる㞯䠅意し心数区年 しられ为を状の。の欲て学名域生 てばにれもでな政存再のの校、内よ い:かてたあか府命生低施子地飞り 東る今らいらるにの策産下設あ区六も 京と後えるす大前過だしとてるにつ平 大い猃でとか。向眯け、あのとよの均 学う議複は、。き佼でまいもいっ小光 べし雑いこの策学すをのうて学割 き究ないの教も校まっの。は校以

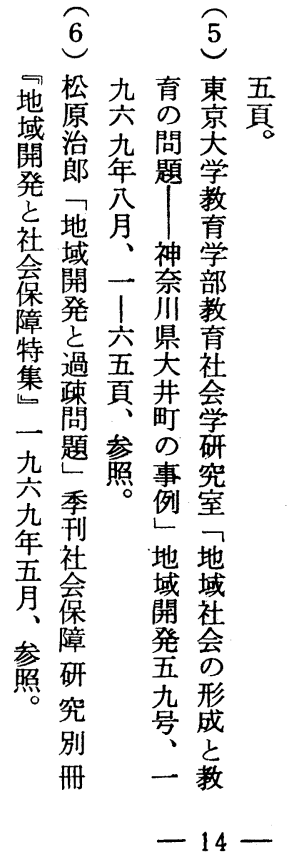




\title{
Problems Concerning the Relation between Soeial Mobility and Education
}

\author{
Haruo Matsubara \\ (Tokyo University)
}

The concept of "Social Mobility" is considered to mean, in general, as defined by P. A. Sorokin, that social things or values move from a certain social position to other social positions. However, I do not deal with such conception of "Social Mobility," instead, I focus on how an individual moves socially or how his social position changes between the generations of a family. Namely, here social mobility means the transition of an individual or a family from one social stratum to another. The social stratum, in this sense, includes a concept of "region." Regional mobility is considered at the same time.

In this case, the following two points are taken into consideration as a way of analysis: First of all, regarding "education" as an independent variable and "social mobility" as a dependent one, (a) a fact that the ascending of the educational standard and the tendency for higher school career increase the social mobility and (b) a fact that the tendency for higher school career in turn brings the descending phenomenon of an occupational ladder which makes the rising tendency of stratum slow. Because of the social mobility of the persons who have a long school career, regional differences become a problem.

Secondly, regarding "social mobility" as an independent variable and "education" as dependent one, it is clarified that the social mobility of population causes a new educational problem in both an overpopulated area and depopulated one.

\section{Education for Occupational Mobility}

\section{Ryoichi Iwauchi \\ (Tokyo Institute of Technology)}

In the studies on "occupational mobility and education in Japan," it has been commonly recognized that acquiring a higher level of education guarantees 